\title{
Transcriptional expression of secondary resistance genes $c c d B$ and repA2 is enhanced in presence of cephalosporin and carbapenem in Escherichia coli
}

Somorita Baishya ${ }^{1}$, Chandrayee Deshamukhya², Jayalaxmi Wangkheimayum², Bhaskar Jyoti Das², Anand Anbarasu, Anupam Das Talukdar ${ }^{1}$, Amitabha Bhattacharjee ${ }^{2}$ and Manabendra Dutta Choudhury ${ }^{1 *}$

\begin{abstract}
Background: The issue of carbapenem resistance in E.coli is very concerning and it is speculated that cumulative effect of both primary resistance genes and secondary resistance genes that act as helper to the primary resistance genes are the reason behind their aggravation. Therefore, here we attempted to find the role of two secondary resistance genes $(S R G) c c d B$ and repA2 in carbapenem resistance in $E$. coli (CRE). In this context influential genes belonging to secondary resistome that act as helper to the primary resistance genes like bla $a_{\mathrm{NDM}}$ and bla $a_{\mathrm{CTX}-\mathrm{M}}$ in aggravating $\beta$-lactam resistance were selected from an earlier reported in silico study. Transcriptional expression of the selected genes in clinical isolates of E.coli that were discretely harboring bla $a_{\mathrm{NDM}-1}, b / a_{\mathrm{NDM}-4}, b / a_{\mathrm{NDM}-5}, b / a_{\mathrm{NDM}-7}$ and bla $a_{\mathrm{CTX}-\mathrm{M}-15}$ with and without carbapenem and cephalosporin stress $(2 \mu \mathrm{g} / \mathrm{ml})$ was determined by real time PCR. Cured mutants sets that were lacking (i) primary resistance genes, (ii) secondary resistance genes and (iii) both primary and secondary resistance genes were prepared by SDS treatment. These sets were then subjected to antibiotic susceptibility testing by Kirby Bauer disc diffusion method.
\end{abstract}

Results: Out of the 21 genes reported in the in silico study, 2 genes viz. repA2 and $c c d B$ were selected for transcriptional expression analysis. repA2, coding replication regulatory protein, was downregulated in response to carbapenems and cephalosporins. $c c d B$, coding for plasmid maintenance protein, was also downregulated in response to carbapenems except imipenem and cephalosporins. Following plasmid elimination assay increase in diameter of zone of inhibition under stress of both antibiotics was observed as compared to uncured control hinting at the reversion of antibiotic susceptibility by the-then resistant bacteria.

Conclusion: SRGs repA2 and $c c d B$ help sustenance of bla $a_{\mathrm{NDM}}$ and $b a_{\mathrm{CTX}-\mathrm{M}}$ under carbapenem and cephalosporin stress.

Keywords: repA2, ccdB, Secondary resistance, Cephalosporin, Carabapenem, Escherichia coli

\footnotetext{
* Correspondence: drmdc@bioinfoaus.ac.in

'Department of Life Science and Bioinformatics, Assam University, Silchar, India

Full list of author information is available at the end of the article
}

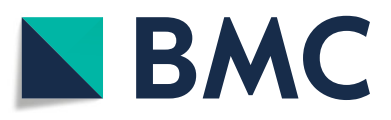

(- The Author(s). 2021 Open Access This article is licensed under a Creative Commons Attribution 4.0 International License, which permits use, sharing, adaptation, distribution and reproduction in any medium or format, as long as you give appropriate credit to the original author(s) and the source, provide a link to the Creative Commons licence, and indicate if changes were made. The images or other third party material in this article are included in the article's Creative Commons licence, unless indicated otherwise in a credit line to the material. If material is not included in the article's Creative Commons licence and your intended use is not permitted by statutory regulation or exceeds the permitted use, you will need to obtain permission directly from the copyright holder. To view a copy of this licence, visit http://creativecommons.org/licenses/by/4.0/. The Creative Commons Public Domain Dedication waiver (http://creativecommons.org/publicdomain/zero/1.0/) applies to the data made available in this article, unless otherwise stated in a credit line to the data. 


\section{Background}

Morbidity and mortality rates due to Gram negative bacterial infections is increasing due to the global threat of antibiotic resistance [1]. This issue is a bane to health care industry as well as to economy $[1,2]$ and dearth in production of newer and efficient antibiotics is contributing to its escalation [3-5]. Dissemination of resistance as featured by Enterobacteriaceae to cephalosporins and carbapenems is concerning $[6,7]$ and incidentally, carbapenems happen to be the drugs of last resort for treating Gram negative bacterial infections [8-10].

The $\beta$ - lactam ring of cephalosporins are hydrolyzed by CTX-M, the most prevalent and clinically relevant extended-spectrum $\beta$ lactamases (ESBLs) while, carbapenems in carbapenem resistant Enterobacteriaceae (CRE) are inactivated by acquiring genes that code for carbapenemases $[7,11,12]$. Reports of dissemination of CTX-M from Europe to Asia indicates its wide spread occurrence and also reflects the associated apprehension $[7,13,14]$. Following the first report of $b l a_{\mathrm{CTX}-\mathrm{M}-15}$ from India many reports of its prevalence was reported from this sub-continent [14]. Likewise, among the commonly produced carbapenemases by CRE, bla $a_{\mathrm{NDM}}$ (New Delhi metallo-beta-lactamase) is one of the most widespread variant in this part of the world $[15,16]$. After the report of first incidence in 2008, several works reporting the mayhem of $b l a_{\mathrm{NDM}}$ has surfaced [17-19]. The probable ineffectiveness of carbapenems is alarming [8, 18] and hence, the need of the hour is to identify newer antibiotic targets that could efficiently reduce the issue in concern [5].

At the onset of developing newer therapeutic regime it is imperative to understand the genetic and molecular mechanisms involved in a system [20]. Holistic models like gene networks designed using high throughput technologies can be used to identify genes, their molecular and biological functions that are essential in a system. Elimination of the same genes from the system will be helpful in confirming their role in the system, thereby posing them as potential novel antimicrobial targets $[4,21]$.

The report published on gene network analysis of CRE harboring bla $a_{\mathrm{NDM}}$ unveiled that apart from the genes primarily associated with CRE like $b l a_{\mathrm{NDM}}$, $a m p C$ some other genes, that are apparently non-essential in imparting carbapenem resistance, play influential role in the system [22]. These genes help the bacteria to survive under therapeutic stress of carbapenems and cephalosporins. Such genes are designated as "Secondary Resistance Genes" (SRG) [4]. This study is a first attempt to validate of the role of SRGs obtained by gene network analysis of CRE. Here the roles of a few selected SRGs (repA2 and $c c d B$ ) were deciphered by studying their transcriptional pattern in response to carbapenems and cephalosporins stress and performing gene elimination assays. Since carbapenem and cephalosporin resistances are plasmid- mediated resistance therefore, repA2 gene which is associated with replication regulation and $c c d B$ which associated with plasmid maintenance protein were selected for the study. Transcriptional response of these genes to antibiotic stress and change in antibiotic susceptibility pattern following gene elimination assays indicated their role as helper to primary resistance genes in aggravating carbapenem resistance. The uniqueness of these genes in relation to homology with human proteins was also checked in order to establish these SRGs as newer antimicrobial targets that might be helpful in revoking carbapenem resistance.

\section{Results}

Transcriptional expression of $c c d B$ and repA2 genes with and without antibiotic stress

$c c d B$ and repA2 genes showed distinct pattern of response in these selected isolates when exposed to carbapenems and cephalosporins (Fig. 1a, b, c, d). However, the expressional pattern upon exposure to quinolones and aminoglycosides were not encouraging as no specific pattern of expression was observed (Supplementary material Fig. 1a, b). Upregulation of $\operatorname{repA} 2$ gene was observed in $b l a_{\mathrm{NDM}-1}, b l a_{\mathrm{NDM}-4}, b l a_{\mathrm{NDM}-5}$ and $b l a_{\mathrm{NDM}-7}$ without antibiotics stress. Down regulation of repA2 gene was observed in all the isolates on exposure to $2 \mu \mathrm{g} / \mathrm{ml}$ of meropenem. Stress of $2 \mu \mathrm{g} / \mathrm{ml}$ of ertapenem showed upregulation of repA2 as compared to control except in isolates harboring $b l a_{\mathrm{NDM}-7}$ however, downregulation of the same gene was seen in all the isolates when compared with the isolates without stress. Under ertapenem pressure the maximal expression value of repA2 was observed in $b l a_{\mathrm{NDM}-1}(\mathrm{RQ}=7.77)$ followed by $b l a_{\mathrm{NDM}-5}(\mathrm{RQ}=3.18)$. In case of $2 \mu \mathrm{g} / \mathrm{ml}$ of imipenem stress, downregulation of repA2 was observed in isolates carrying bla $a_{\mathrm{NDM}-1}$ and $b l a_{\mathrm{NDM}-5}$, while, isolates carrying $b l a_{\mathrm{NDM}-4}, b l a_{\mathrm{NDM}-7}$ showed upregulation. However, if compared to without stress isolates, repA2 was downregulated in isolates carrying bla $a_{\mathrm{NDM}-7}$. ANOVA test showed expression of repA2 in response to carbapenems in $b l a_{\mathrm{NDM}}$ isolates were statistically significant (pvalue $=0.05$ ). Downregulation of $\operatorname{repA} 2$ was also seen in isolates that were harboring $b l a_{\mathrm{CTX}-\mathrm{M}-15}$ both when no cephalosporin stress was given as well as when $2 \mu \mathrm{g} / \mathrm{ml}$ of cephalosporins viz. ceftazidime, cefotaxime and ceftriaxone stress was applied. ANOVA test showed that $p$ value of repA2 as 0.99 in response to cephalosporins in bla $\mathrm{CTX-M-15}$ isolates. Upregulation of $c c d B$ gene was observed in isolates that were bearing $b l a_{\mathrm{NDM}-4}, b l a_{\mathrm{NDM}-5}$ and bla $a_{\mathrm{CTX}-\mathrm{M}-15}$ on which no antibiotic stress was applied. Imipenem stress of $2 \mu \mathrm{g} / \mathrm{ml}$ upregulated the expression level of $c c d B$ in all the isolates and the maximal 


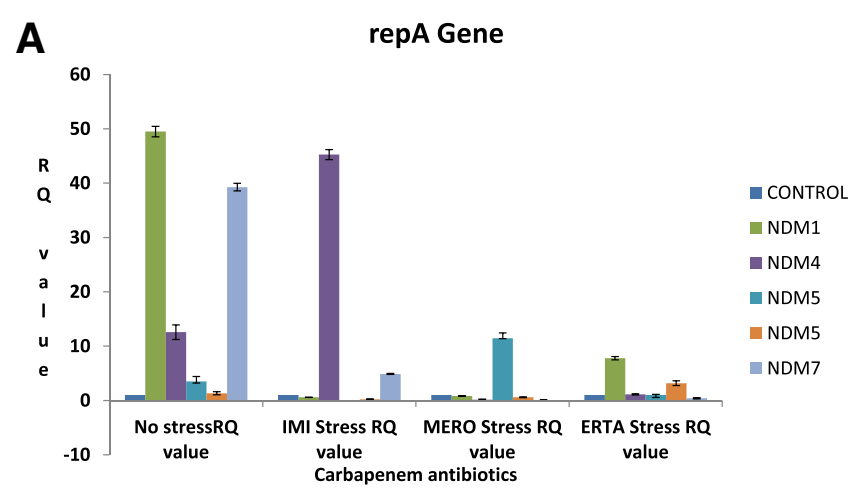

B
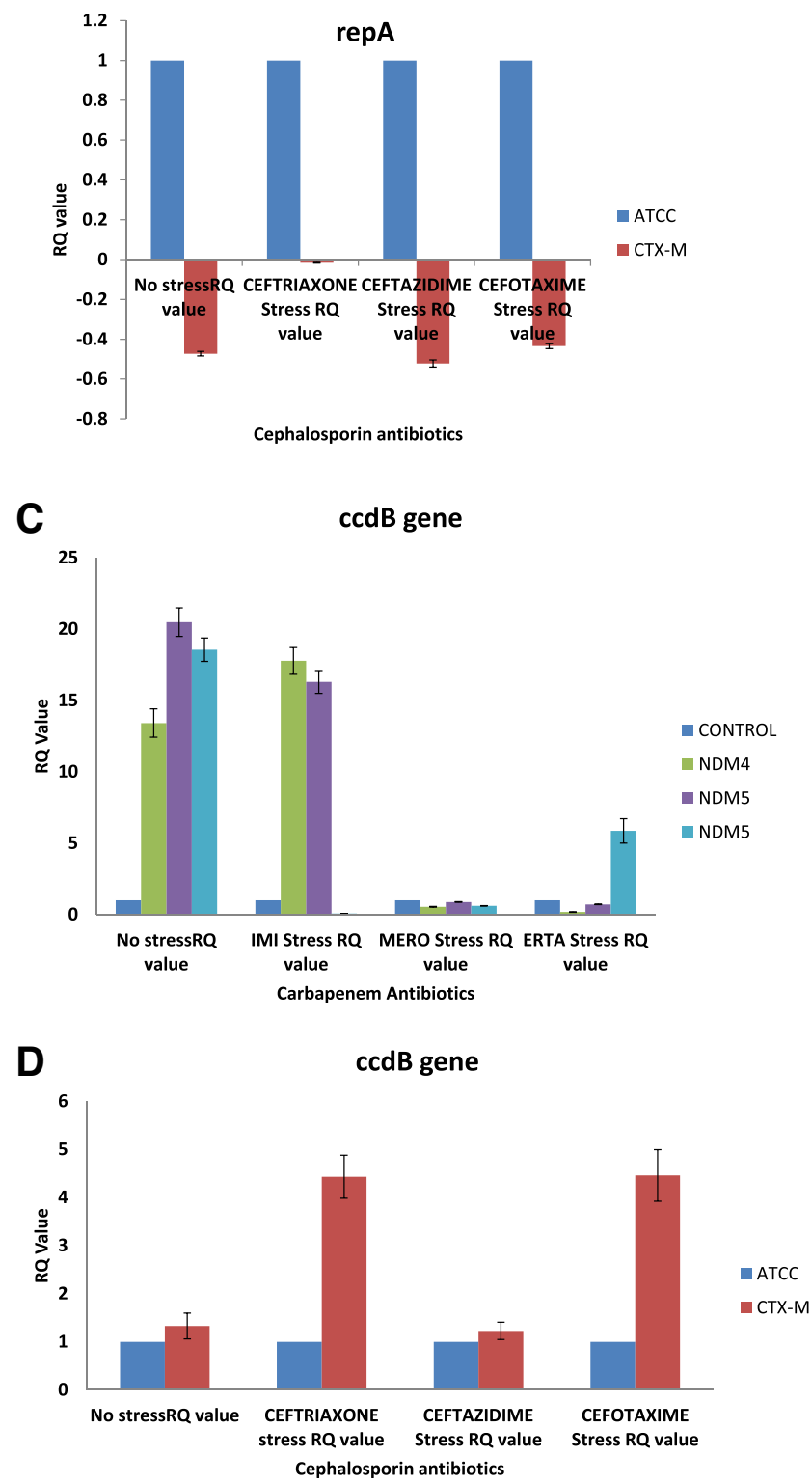

Fig. 1 a Transcriptional response of repA2 to carbapenems. b Transcriptional response of repA2 to cephalosporins. c Transcriptional response of $c c d B$ to carbapenems. d Transcriptional response of $c c d B$ to cephalosporins 
transcription level was shown by bla $a_{\mathrm{NDM}-4}(\mathrm{RQ}=17.67)$. Meropenem and ertapenem stress of equal volume showed downregulation of the gene in all the isolates. ANOVA test showed that $p$-value of $c c d B$ as 0.09 in response to carbapenems in $b l a_{\mathrm{NDM}}$ isolates. Ceftazidime, cefotaxime and ceftriaxone stresses at $2 \mu \mathrm{g} / \mathrm{ml}$ showed upregulation of $c c d B$ however, if compared with without stress isolates $c c d B$ was downregulated. ANOVA test showed that $p$-value of $c c d B$ as 0.67 in response to cephalosporins in bla $\mathrm{CTX-M-15}$ isolates.

\section{Susceptibility testing of mutants lacking primary and secondary resistance genes}

Complete elimination of primary resistance genes viz. $b l a_{\mathrm{NDM}}$ and $b l a_{\mathrm{CTX}-\mathrm{M}-15}$ after 3 passages and secondary resistance genes viz. $c c d B$ and $\operatorname{rep} A 2$ after single passage was confirmed by PCR assay. Hence 6 sets of mutants as mentioned in methodology section were obtained.

Cured mutants were subjected to disc diffusion method and their susceptibility to various carbapenems and cephalosporins were compared against an uncured control. The zone diameter had increased in all the mutant plates compared to the control plate indicating that elimination of the genes had revoked resistance of the isolates to both the antibiotic groups. The measurements of zone of inhibitions of the mutants and uncured isolates against each antibiotic are given in Table $1 \mathrm{a}$ and $\mathrm{b}$.

\section{Discussion}

The issues of antimicrobial resistance specifically towards carbapenems require immediate attention. Developing a holistic model to visualize and decipher the role of genes of secondary resistome along with the primary resistance genes is explicit $[4,22]$. Genes associated with CRE is considered in this study. Reports of association of SRGs with carbapenem resistance are not found yet.

From the 21 genes that had been streamlined from in silico analysis [22] two genes viz. $c c d B$ (cluster 19) involved with plasmid maintenance protein and repA2 (cluster 33) associated with replication regulatory protein have been filtered out for in vitro transcriptional analysis. There are no reports of these genes of secondary resistome to be involved with carbapenem resistance owing to the presence of $b l a_{\mathrm{NDM}}$ genes.

The response patterns of expression profiles of repA2 and $c c d B$ genes on carbapenem and cephalosporin exposure on clinical isolates of E.coli discretely harboring $b l a_{\mathrm{NDM}-1}, b l a_{\mathrm{NDM}-4}, b l a_{\mathrm{NDM}-5}, b l a_{\mathrm{NDM}-7}$ and $b l a_{\mathrm{CTX}-\mathrm{M}-15}$

Table 1 (a) and (b): Measurements of zone of inhibitions of the mutants and uncured isolates against each antibiotic

\begin{tabular}{|c|c|c|c|c|c|c|}
\hline \multicolumn{7}{|l|}{ (a) } \\
\hline $\begin{array}{l}\text { Sl. } \\
\text { No }\end{array}$ & Antibiotic & $\begin{array}{l}\text { Uncured isolate } \\
(\mathrm{mm})\end{array}$ & \multicolumn{2}{|l|}{$\Delta$ blaNDM } & $\Delta$ blaNDM $\Delta$ repA2 (mm) & $\Delta$ blaNDM $\Delta c c d B \Delta r e p A 2(\mathrm{~mm})$ \\
\hline 1 & Meropenem & 0 & \multicolumn{2}{|l|}{12} & 12 & 21 \\
\hline 2 & Imipenem & 16 & \multicolumn{2}{|l|}{19} & 19 & 25 \\
\hline 3 & Ertapenem & 0 & \multicolumn{2}{|l|}{13} & 13 & 27 \\
\hline 4 & Ampicillin & 0 & \multicolumn{2}{|l|}{0} & 0 & 0 \\
\hline 5 & Ceftazidime & 0 & \multicolumn{2}{|l|}{0} & 0 & 25 \\
\hline 6 & Amikacin & 21 & \multicolumn{2}{|l|}{30} & 30 & 26 \\
\hline 7 & Gentamicin & 25 & \multicolumn{2}{|l|}{24} & 24 & 22 \\
\hline 8 & Ciprofloxacin & 0 & \multicolumn{2}{|l|}{0} & 0 & 32 \\
\hline 9 & Cefepime & 0 & \multicolumn{2}{|l|}{0} & 0 & 26.5 \\
\hline \multicolumn{7}{|l|}{ (b) } \\
\hline $\begin{array}{l}\text { Sl. } \\
\text { No }\end{array}$ & Antibiotic & $\begin{array}{l}\text { Uncured isolate } \\
(\mathrm{mm})\end{array}$ & $\begin{array}{l}\Delta \text { blaCTX-M-15 } \\
(\mathrm{mm})\end{array}$ & $\begin{array}{l}\Delta \text { blaCTX-M-15 } \Delta c c d B \\
(\mathrm{~mm})\end{array}$ & $\begin{array}{l}\Delta \text { blaCTX-M-15 } \Delta \text { repA2 } \\
(\mathrm{mm})\end{array}$ & $\begin{array}{l}\Delta \text { blaCTX-M-15 } \Delta c c d B \Delta r e p A 2 \\
(\mathrm{~mm})\end{array}$ \\
\hline 1 & Ciprofloxacin & 0 & 0 & 5 & 5 & 32 \\
\hline 2 & Gentamicin & 22 & 23 & 29 & 30 & 24 \\
\hline 3 & Imipenem & 18 & 20 & 23 & 21 & 25 \\
\hline 4 & Meropenem & 18 & 20 & 23 & 20 & 26 \\
\hline 5 & Amikacin & 20 & 26 & 30 & 30 & 28 \\
\hline 6 & Ertapenem & 17 & 20 & 23 & 22 & 25 \\
\hline 7 & Ampicillin & 0 & 5 & 8 & 8 & 16 \\
\hline 8 & Ceftazidime & 10 & 13 & 18 & 18 & 25 \\
\hline 9 & Cefepime & 0 & 8 & 13 & 13 & 26 \\
\hline
\end{tabular}


were interesting. Elimination of these SRGs is essential for prediction of their role in a system [23].

repA2 gene in the clinical samples was down regulated on exposure to imipenem, meropenem and ertapenem and under ertapenem pressure maximal expression was seen in the isolate harbouring $b l a_{\mathrm{NDM}-1}$. Similarly, on various cephalosprins exposure repA2 gene was down regulated. Eliminating repA2 genes also showed changes in the susceptibility pattern against the antibiotics in concern. repA2, a replication initiation protein, controls replication of the plasmids belonging to IncFII group. The expression of this gene is regulated by the promoters situated at its upstream region. $5^{\prime}$ end of RNA$\mathrm{CX}$, a constitutively produced transcript, encodes repA2 which acts as a repressor. This repressor regulates expression of RNA-A, another transcript. RNA-E, produced by the anti-parallel DNA strand regulates the translation of both RNA-CX and RNA-A. Hence, RNAE directly interacts with both RNA-CX and RNA-A and can inhibit their translation. In this way repA2 regulates plasmid copy number $[24,25]$. Reports also show that mutations in repA2 gene can increase plasmid copy number [26] while its disruption can stop the plasmid replication [27].

Congruent to literature, change in transcriptional response pattern of repA2 upon antibiotic exposure as well as change in antibiotic susceptibility pattern upon its elimination was seen in this study. Due to these changes repA2 can be considered as an indicator of antibiotic stress [28]. Since, plasmids play a crucial role in dissemination of antibiotic resistance and increase in the plasmid copy number gives bacteria better chances to adapt to antibiotic stress [29], therefore, disrupting repA2 gene activity [27] might inactivate replication. The increase in diameters of zone of inhibition upon elimination of repA2 as seen in this study indicates that elimination of this gene from E.coli system leads to loss of plasmid thereby rendering $E$. coli of clinical relevance nonpathogenic. These characteristics make repA2 a good candidate for designing gene marker [30] From this finding it can be considered that repA2 gene plays a crucial role as helper to the primary carbapenem resistance genes and its elimination might also be able to revoke carbapenem resistance and thus help in solving the problem of antibiotic resistance [31].

The $c c d B$ gene, associated with plasmid maintenance, was down regulated when all the above mentioned clinical isolates were put under meropenem, ertapenem and all the three cephalosporins pressure. However, imipenem stress showed over expression of $c c d B$ gene. Elimination of $c c d B$ genes showed increase in the zone of inhibition indicating changes in the susceptibility pattern against the antibiotics in concern. The $c c d B$ operon (control of cell death), a type of plasmid addiction system (PAS), is encoded by IncF plasmid to maintain plasmid stability in E. coli [32]. The operon consists of $c c d B A$ and $c c d B$ genes that codes for a toxin-antitoxin system which work in unison to maintain plasmid replication during cell division in host [33, 34]. The $c c d B$ gene encodes DNA gyrase poison that can induce double strand breaks in E. coli, ultimately killing it [35]. This mechanism is activated only when the plasmid copy numbers decreases. Typically, gene $c c d B A$ binds tightly to $c c d B$ and encodes an antitoxin that inhibits the toxic activity of $c c d B$ gene. On losing F-plasmid, Lon protease, a substrate for $c c d B A$, degrades it leaving $c c d B$ free to act upon DNA gyrase [32, 35]. GyrA subunit is an antibiotic target for quinolones, however, quinolone resistant bacteria have no effect on $c c d B$ indicating that $c c d B$ and GyrA subunits interact at different sites [35]. Increase in the diameter of zone of inhibition upon elimination of $c c d B$ genes as seen in this study hints that this gene supports the survival of $E$. coli under therapeutic stress condition and on its elimination the toxic function of this gene activates in order to maintain the PAS. All these findings make $c c d B$ gene, a member of PAS, an interesting antibiotic target that could yield desirable results against carbapenem resistance $[32,36]$.

\section{Conclusion}

As real is the issue of carbapenem resistance, so is the need to search and design newer antibiotic targets. Since the genes of secondary resistome act as helper to the genes primarily associated with carbapenem resistance, they can be regarded as potential drug targets for designing newer antibiotics. Revokement of resistance upon elimination of $c c d B$ and repA2 genes indicate that genes of secondary resistome do act as helper to primary resistance genes like $b l a_{\mathrm{NDM}}$ thereby aggravating carbapenem resistance.

\section{Materials and methods}

Selection of genes from in silico analysis of gene network of carbapenem resistant enterobacteriaceae

From the in silico report published [22] in 2019 on potential drug targets against CRE using gene network analysis, $c c d B$ and repA2 from clusters 19 and 33 respectively were selected for transcriptional expression analysis with and without antibiotic stress. $c c d B$ gene is associated with plasmid maintenance whereas repA2 regulates plasmid replication.

\section{Bacterial isolates}

Each clinical isolates of $E$. coli selected for the study were individually harboring $b l a_{\mathrm{NDM}-1}, \quad b l a_{\mathrm{NDM}-4}$, $b l a_{\mathrm{NDM}-5}, b l a_{\mathrm{NDM}-7}$ and $b l a_{\mathrm{CTX}-\mathrm{M}-15}$. Single strains $b l a_{\mathrm{NDM}-1}, b l a_{\mathrm{NDM}-4}, b l a_{\mathrm{NDM}-7}$ and $b l a_{\mathrm{CTX}-\mathrm{M}-15}$, and two strains of $b l a_{\mathrm{NDM}-5}$ were used for the study. E. coli 
ATCC 25922 was used as control for the study. PCR was done to confirm that all the isolates possessed $b l a_{\mathrm{NDM}}, b l a_{\mathrm{CTX}-\mathrm{M}}, c c d B$ and repA2genes. Primers were used in this study to confirm their presence is given in Table 2.

\section{Transcriptional expression of $c c d B$ and repA2 genes with and without antibiotic stress}

The transcriptional response of $c c d B$ and repA2 genes in the isolates was determined by quantitative real time PCR. The isolates harboring $b l a_{\mathrm{NDM}}$ and $b l a_{\mathrm{CTX}-\mathrm{M}-15}$ were cultured overnight with $2 \mu \mathrm{g} / \mathrm{ml}$ carbapenem (imipenem, meropenem, ertapenem), cephalosporin (cefotaxime, ceftriaxone, ceftazidime), quinolone (cipfrofloxacin, norfloxacin) and aminoglycoside (gentamicin, amikacin) stress respectively. The isolates were also cultured under normal condition i.e. without any antibiotic pressure. Total mRNA was isolated from the overnight cultures grown to log phase using RNeasy kit (Qiagen, India). cDNA was prepared from the isolated mRNA using the Quanti Tect Reverse Transcription kit (Qiagen, India) following the manufacturer's protocol. The cDNA generated was quantified by Picodrop (Pico 200, Cambridge, UK) and was then used as template for quantitative real time PCR using the Power Sybr Green Master Mix (Applied Biosystem, Warrington, UK) in Step One Plus realtime detection system. The relative quantity of the expression of $c c d B$ and repA2 genes in the isolates was evaluated using the $\Delta \Delta c$ t method in reference to the corresponding expression of the genes in E. coli ATCC 25922. 30S ribosomal protein subunit rpsl gene of $E$. coli was also used in parallel as an internal control throughout the reactions.

\section{Susceptibility testing of mutants lacking primary and secondary resistance genes}

The isolates harboring both the primary $\left(b l a_{\mathrm{NDM}}\right.$ and bla $\left.a_{\mathrm{CTX}-\mathrm{M}-15}\right)$ and secondary ( $c c d B$ and repA2) resistance genes were eliminated by treatment with SDS. Randomly five to six single colonies of each of the isolates was inoculated in fresh $5 \mathrm{ml}$ Luria Bertani broth supplemented with SDS consecutively ranging from a concentration of

Table 2 Primers used in this study

\begin{tabular}{llll}
\hline Primer pairs & Target & Sequence & Reference \\
\hline NDM-F & NDM & 5'-GGGCAGTCGCTTCCAACGGT-3' & {$[37]$} \\
NDM-R & & 5'-GTAGTGCTCAGTGTCGGCAT-3' & \\
CTX-M-F & CTX-M & 5'-CGCTITGCGATGTGCAG-3' & {$[37]$} \\
CTX-M-R & & 5'-ACCGCGATATCGTGGT-3' & \\
ccdB-F & ccdB & 5'-CGAAGCGGGAATGCGGTAAT-3' & This study \\
ccdB-R & & 5'-CATCCTGCTATCTGGCTCCT-3' & \\
repA2-F & repA2 & 5'-AGGCCCGGTAAAAGACAGG-3' & This study \\
repA2-R & & 5'-CAAAGTCGCTCTGCGTTTCA-3' & \\
\hline
\end{tabular}

2 to $8 \%$ and incubated overnight. The following sets of cured mutants were generated:

i) E. coli $\Delta$ bla $_{\mathrm{NDM}} \Delta \mathrm{ccdB}$

ii) E. coli $\Delta$ bla $_{\mathrm{NDM}} \Delta \mathrm{ccdB} \Delta \mathrm{repA} 2$

iii) E. coli $\Delta$ bla $_{\mathrm{CTX}-\mathrm{M}-15}$

iv) E. coli $\Delta$ bla $_{\mathrm{CTX}-\mathrm{M}-15} \Delta \mathrm{ccdB}$

v) E. coli $\Delta$ bla $_{\text {CTX-M-15 }} \Delta$ repA2

vi) E. coli $\Delta$ bla $_{\mathrm{CTX} \text {-M-15 }} \Delta \mathrm{ccdB} \Delta \mathrm{repA} 2$

All the above sets of mutants were then tested for antibiotic susceptibility by Kirby Bauer disc diffusion method. The antibiotics used were imipenem, meropenem, ertapenem, cefotaxime, cefepime, ceftazidime, ciprofloxacin, ampicillin, gentamicin and amikacin respectively. The diameter of the zone of inhibition of the mutants against each antibiotic was measured and compared to the diameter of zone of inhibition of the uncured isolate.

\section{Statistical analysis}

The changes in expression of $b l a_{\mathrm{NDM}}$ and $b l a_{\mathrm{CTX}-\mathrm{M}-15}$ in response to different carbapenem and cephalosporin stresses at $2 \mu \mathrm{g} / \mathrm{ml}$ concentration were analyzed using one-way ANOVA. Differences were considered statistically significant at when $p$ value $\leq 0.05$.

\section{Abbreviations}

CRE: Carbapenem resistant Enterobacteriaceae; ESBL: Extended-spectrum $\beta$ lactamases; PAS: Plasmid addiction system; PCR: Polymerase chain reaction; RNA: Ribonucleic acid; SDS: Sodium dodecyl sulfate; SRG: Secondary resistance genes

\section{Supplementary Information}

The online version contains supplementary material available at https://doi. org/10.1186/s12866-021-02136-y.

Additional file 1: Supplementary material Fig A. Transcriptional response of repA2 to aminoglycosides and quinolones. Fig B.

Transcriptional response of $c c d B$ to aminoglycosides and quinolones

\section{Acknowledgements}

The authors are grateful to DBT (Govt. of India) sponsored Bioinformatics Infrastructure Facility (BIF) of Assam University, India and DelCON's e-Journal Access Facility. Authors also acknowledge Indian Council of Medical Research, New Delhi for providing SRF.

\section{Authors' contributions}

SB has analyzed and wrote the manuscript, SB, CD, JW and BJD have curated data for the work, AA, ADT, AB and MDC have conceptualized, designed and reviewed the work. The authors read and approved the final manuscript.

\section{Funding}

Part of the work was funded by Indian Council of Medical Research, vide letter no. AMR/Fellowship/19/2019-ECD-11 dtd. 08.07.2019. However the funding agency had no role in the design of the study and collection, analysis, and interpretation of data and in writing the manuscript.

Availability of data and materials

The datasets used and analysed in the current study are available from the corresponding author upon request. 


\section{Declarations}

\section{Ethics approval and consent to participate}

Not applicable.

\section{Consent for publication}

Not applicable.

\section{Competing interests}

The authors declare that they have no competing interests.

\section{Author details}

'Department of Life Science and Bioinformatics, Assam University, Silchar, India. ${ }^{2}$ Department of Microbiology, Assam University, Silchar, India. ${ }^{3}$ Medical \& Biological Computing Laboratory, School of Biosciences \& Technology, VIT University, Vellore, India.

Received: 26 August 2020 Accepted: 26 February 2021

Published online: 09 March 2021

\section{References}

1. Cosgrove SE, Kaye KS, Eliopoulous GM, Carmeli Y. Health and economic outcomes of the emergence of third-generation cephalosporin resistance in Enterobacter species. Arch Intern Med. 2002;162(2):185-90.

2. O'Neill J. Tackling a global health crisis: initial steps. In: The Review on Antimicrobial Resistance Chaired by Jim O’Neill; 2015.

3. Charles PG, Grayson ML. The dearth of new antibiotic development: why we should be worried and what we can do about it. Med J Aust. 2004; 181(10):549-53.

4. Jana B, Cain AK, Doerrler WT, Boinett CJ, Fookes MC, Parkhill J, et al. The secondary resistome of multidrug-resistant Klebsiella pneumoniae. Sci Rep. 2017;7:42483.

5. Peleg AY, Hooper DC. Hospital-acquired infections due to gram-negative bacteria. N Engl J Med. 2010;362(19):1804-13.

6. Paterson DL. Resistance in gram-negative bacteria: Enterobacteriaceae. Am J Infect Control. 2006:34(5):S20-S8.

7. Pitout JD, Laupland KB. Extended-spectrum $\beta$-lactamase-producing Enterobacteriaceae: an emerging public-health concern. Lancet Infect Dis. 2008;8(3):159-66.

8. Codjoe FS, Donkor ES. Carbapenem resistance: a review. Med Sci. 2018;6(1):1

9. Lutgring JD, Limbago BM. The problem of carbapenemase-producingcarbapenem-resistant-Enterobacteriaceae detection. J Clin Microbiol. 2016; 54(3):529-34.

10. Alotaibi F. Carbapenem-resistant Enterobacteriaceae: an update narrative review from Saudi Arabia. J infect Public Health. 2019:12:465-71.

11. Perez F, Van Duin D. Carbapenem-resistant Enterobacteriaceae: a menace to our most vulnerable patients. Cleve Clin J Med. 2013;80(4):225.

12. D'Andrea MM, Arena F, Pallecchi L, Rossolini GM. CTX-M-type $\beta$-lactamases: a successful story of antibiotic resistance. Int J Med Microbiol. 2013;303(6-7): 305-17.

13. Park SH. Third-generation cephalosporin resistance in gram-negative bacteria in the community: a growing public health concern. Korean $J$ Intern Med. 2014;29(1):27.

14. Ensor V, Shahid M, Evans J, Hawkey P. Occurrence, prevalence and genetic environment of CTX-M $\beta$-lactamases in Enterobacteriaceae from Indian hospitals. J Antimicrob Chemother. 2006:58(6):1260-3.

15. Khan AU, Maryam L, Zarrilli R. Structure, genetics and worldwide spread of New Delhi Metallo- $\beta$-lactamase (NDM): a threat to public health. BMC Microbiol. 2017;17(1):101

16. Sharma A, Bakthavatchalam YD, Gopi R, An S, Verghese VP, Veeraraghavan B. Mechanisms of carbapenem resistance in K. pneumoniae and E. coli from bloodstream infections in India. J Infect Dis Ther. 2016;4:293.

17. Jamal WY, Albert MJ, Rotimi VO. High prevalence of New Delhi metallo- $\beta$ lactamase-1 (NDM-1) producers among carbapenem-resistant Enterobacteriaceae in Kuwait. PLoS One. 2016;11(3):e0152638.

18. Mohapatra PR. Metallo- $\beta$-lactamase 1-why blame new Delhi \& India? Indian Med Res. 2013;137(1):213.

19. Paul D, Bhattacharjee A, Bhattacharjee D, Dhar D, Maurya AP, Chakravarty A. Transcriptional analysis of Bla NDM-1 and copy number alteration under carbapenem stress. Antimicrobial Resist Infect Contr. 2017;6(1):26.
20. Dembek M, Barquist L, Boinett CJ, Cain AK, Mayho M, Lawley TD, et al. Highthroughput analysis of gene essentiality and sporulation in Clostridium difficile. MBio. 2015;6(2):e02383-14.

21. Parimelzaghan A, Anbarasu A, Ramaiah S. Gene network analysis of metallo beta lactamase family proteins indicates the role of gene partners in antibiotic resistance and reveals important drug targets. J Cell Biochem. 2016;117(6):1330-9.

22. Baishya S, Banik SK, Talukdar AD, Anbarasu A, Bhattacharjee A, Choudhury MD. Full title: identification of potential drug targets against carbapenem resistant Enterobacteriaceae (CRE) strains using in silico gene network analysis. Gene Rep. 2019;14:129-37.

23. Le Roux F, Binesse J, Saulnier D, Mazel D. Construction of a Vibrio splendidus mutant lacking the metalloprotease gene vsm by use of a novel counterselectable suicide vector. Appl Environ Microbiol. 2007;73(3):777-84.

24. Dong X, Womble DD, Luckow VA, Rownd RH. Regulation of transcription of the repA1 gene in the replication control region of IncFIl plasmid NR1 by gene dosage of the repA2 transcription repressor protein. J Bacteriol. 1985; 161(2):544-51.

25. del Solar GH, de la Campa AG, Pérez-Martin J, Choli T, Espinosa M. Purification and characterization of RepA, a protein involved in the copy number control of plasmid pLS1. Nucleic Acids Res. 1989;17(7):2405-20.

26. Liu CP. Churchward G, Caro L. The repA2 gene of the plasmid R100. 1 encodes a represser of plasmid replication. Plasmid. 1983;10(2):148-55

27. Light J, Molin S. Post-transcriptional control of expression of the repA gene of plasmid R1 mediated by a small RNA molecule. EMBO J. 1983;2(1):93-8.

28. Pérez-Martín J, Espinosa M. The RepA repressor can act as a transcriptional activator by inducing DNA bends. EMBO J. 1991;10(6):1375-82.

29. San Millan A, Santos-Lopez A, Ortega-Huedo R, Bernabe-Balas C, Kennedy SP, Gonzalez-Zorn B. Small-plasmid-mediated antibiotic resistance is enhanced by increases in plasmid copy number and bacterial fitness. Antimicrob Agents Chemother. 2015;59(6):3335-41.

30. Sanchez-Romero JM, Diaz-Orejas R, De Lorenzo V. Resistance to tellurite as a selection marker for genetic manipulations of Pseudomonas strains. Appl Environ Microbiol. 1998;64(10):4040-6

31. Giraldo R, Fernández-Tornero C, Evans PR, Díaz-Orejas R, Romero A. A conformational switch between transcriptional repression and replication initiation in the RepA dimerization domain. Nat Struct Mol Biol. 2003:10(7):565.

32. Wang H, Bian X, Xia L, Ding X, Müller R, Zhang Y, et al. Improved seamless mutagenesis by recombineering using $\mathrm{ccdB}$ for counterselection. Nucleic Acids Res. 2013;42(5):e37.

33. Ogura T, Hiraga S. Mini-F plasmid genes that couple host cell division to plasmid proliferation. Proc Natl Acad Sci. 1983:80(15):4784-8.

34. Kwak YG, Jacoby GA, Hooper DC. Effect of Qnr on plasmid gyrase toxins CcdB and ParE. Antimicrob Agents Chemother. 2015;59(8):5078-9.

35. Loris R, Dao-Thi M-H, Bahassi EM, Van Melderen L, Poortmans F, Liddington $\mathrm{R}$, et al. Crystal structure of $\mathrm{CcdB}$, a topoisomerase poison from $\mathrm{E}$. coli. J Mo Biol. 1999;285(4):1667-77.

36. Tsang J. Bacterial plasmid addiction systems and their implications for antibiotic drug development. Postdoc J. 2017;5(5):3.

37. Paul D, Dhar D, Maurya AP, Mishra S, Sharma GD, Chakravarty A, et al. Occurrence of co-existing Bla VIM-2 and Bla NDM-1 in clinical isolates of Pseudomonas aeruginosa from India. Ann Clin Microbiol Antimicrob. 2016; 15(1):31.

\section{Publisher's Note}

Springer Nature remains neutral with regard to jurisdictional claims in published maps and institutional affiliations.

Ready to submit your research? Choose BMC and benefit from:

- fast, convenient online submission

- thorough peer review by experienced researchers in your field

- rapid publication on acceptance

- support for research data, including large and complex data types

- gold Open Access which fosters wider collaboration and increased citations

- maximum visibility for your research: over $100 \mathrm{M}$ website views per year

At BMC, research is always in progress.

Learn more biomedcentral.com/submissions 